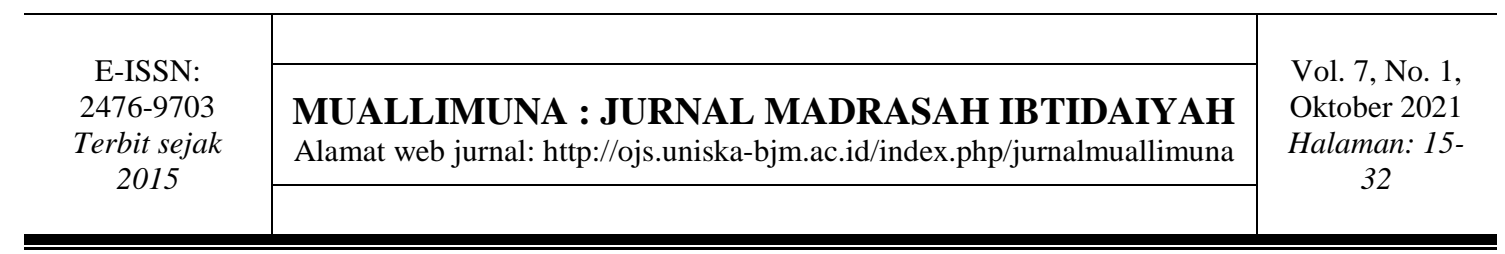

\title{
STRATEGI GURU DALAM MENGOPTIMALKAN KECERDASAN MAJEMUK DI SEKOLAH DASAR
}

\author{
Robiatul Munajah ${ }^{1}$, Asep Supena ${ }^{2}$ \\ ${ }^{1}$ Program Studi Guru Sekolah Dasar, Universitas Trilogi \\ ${ }^{2}$ Program Pascasarjana Pendidikan Dasar, Universitas Negeri Jakarta \\ ${ }^{1}$ nengrobiatulmunajah@trilogi.ac.id, ${ }^{2}$ supena2007@yahoo.com
}

\begin{abstract}
Abstrak: Keberhasilan siswa dalam belajar tidak hanya tergantung pada kemampuan mereka sendiri. Beberapa faktor yang dapat memberikan pengaruh perlu dioptimalkan. Strategi guru sangat berarti untuk mengoptimalkan kecerdasan majemuk siswa sesuai indikator yang dimiliki setiap siswa. Setiap anak di dunia ini memiliki berbagai kecerdasan dalam tingkat dan indikator yang berbeda. Hal ini menunjukkan bahwa semua anak, pada hakikatnya, adalah cerdas. Perbedaan terletak pada tingkatan dan indikator kecerdasannya. Perbedaan tersebut ditentukan oleh berbagai faktor. Salah satunya adalah rangsangan yang diberikan pada saat anak belajar dalam proses pembelajaran yang dilakukan oleh guru. Perbedaan kecerdasan di antara anak didik menuntut cara berpikir pendidik yang adil dan eksistensial. Penelitian ini merupakan kajian literatur untuk melihat lebih spesifik strategi guru dalam mengoptimalkan kecerdasan majemuk di sekolah dasar berdasar sumber referensi penelitian dan buku. Pendidik yang baik mampu mendeteksi kecerdasan anak dengan cara mengamati perilaku, kecenderungan, minat, cara dan kualitas anak saat bereaksi terhadap stimulus yang diberikan. Semua indikator kecerdasan dapat dikenali pendidik untuk kemudian dibuat profil kecerdasannya. Oleh karena itu, sebaiknya setiap guru mengetahui cara mengembangkan kecerdasan anak didiknya, dengan cara mengidentifikasi setiap indikator kecerdasan anak dan menyadari pentingnya pengembangan semua kecerdasan yang dimiliki siswa nya.
\end{abstract}

\section{Kata Kunci: Strategi Guru; Kecerdasan Majemuk.}

\section{TEACHER'S STRATEGY IN OPTIMIZING MULTIPLE INTELEGENCES IN ELEMENTARY SCHOOL}

Abstract: The success of students in learning does not only depend on their own abilities. Several factors that can give effect need to be optimized. The teacher's strategy is very meaningful to optimize students' multiple intelligences according to the indicators that each student has. Every child in this world has various intelligences in different levels and indicators. This shows that all children, by nature, are intelligent. The difference lies in the level and indicators of intelligence. These differences are determined by various factors. One of them is the stimulation given when children learn in the learning process carried out by the teacher. The difference in intelligence among students demands a fair and existential way of thinking of educators. This research is a literature review to see more specifically the teacher's strategy in optimizing multiple intelligences in elementary schools based on research reference sources and books. 
Good educators are able to detect children's intelligence by observing the behavior, tendencies, interests, ways and qualities of children when reacting to the given stimulus. All indicators of intelligence can be recognized by educators to then make a profile of intelligence. Therefore, every teacher should know how to develop the intelligence of their students, by identifying each indicator of children's intelligence and realizing the importance of developing all the intelligences of their students.

\section{Keywords: Teacher Strategy; Multiple Intelligences.}

\section{PENDAHULUAN}

Pendidikan secara global merupakan sebuah usaha yang ditempuh untuk dapat mewujudkan masa depan ataupun peradaban sebuah negara. Pendidikan pada dasarnya merupakan upaya memanusiakan manusia, dengan pendidikan diharapkan mampu menumbuhkan serta mengembangkan potensi yang dimilikinya. Manusia yang berpendidikan diharapkan mampu untuk mengembangkan dirinya sendiri, lingkungan sekitarnya, dan masa depan bangsa serta negaranya. Manusia berpendidikan dibutuhkan oleh bangsa ini untuk mampu mengembangkan potensi bangsa yang sudah ada serta meningkatkan potensi dari yang sudah ada sebelumnya (Nasional \& Ekonomi, n.d.). Namun tidak dapat dipungkiri bahwa kualitas pendidikan Indonesia masih pada tahap yang terus diperbaiki dari masa ke masa. Generasi penerus bangsa lebih menyukai untuk bersekolah ataupun melanjutkan pendidikannya di luar negeri, dengan tujuan untuk mengembangkan kemampuannya serta menunjang kehidupan selanjutnya. Alasan tersebut juga ditunjang oleh alasan kuat yaitu kualitas pendidikan di Indonesia masih terus mengalami perbaikan dan sistemnya yang terus berubah-ubah.

Pendidikan Indonesia memang belum bisa dikatakan sebagus negara maju di Eropa ataupun negara tetangga di kawasan Asia Tenggara lainnya. Menurut Survei dalam jurnal yang dituliskan Pratiwi dalam jurnal nya kemampuan pelajar yang dirilis oleh Programme for Internasional Student Assessment (PISA) yang dilaksanakan di Paris pada tanggal 3 Desember 2018, menempatkan Indonesia pada peringkat ke-72 dari 77 negara. Kualitas pendidikan di Indonesia masih jauh di bawah negara-negara tetangga seperti Malaysia, Brunei Darussalam, dan Singapura (Pratiwi, 2019). Hal yang mendasarkan penyebab lemahnya hasil pendidikan di Indonesia saat ini adalah tujuan pendidikan disekolah tidak bersifat holistik dan utuh, sehingga belum membangun dan menumbuhkan potensi kecakapan pada diri siswa. Hal ini sesuai dengan Pangesti saat seminar internasional yang dituliskan dalam jurnalnya halaman 26, kecakapan ini dapat dimanfaatkan untuk membantu menyelesaikan permasalahan hidup manusia. Sayangnya, hanya sebagian kecil pendidikan Indonesia yang memanfaatkan kemampuan ini. Konsep dasar matematika, misalnya menghitung mungkin telah dikuasai tetapi keterampilan mengaplikasikan konsep tersebut dalam situasi nyata dan masalah tidak terstruktur kadang diabaikan (Sri, 2017).

Sementara itu dilihat dari sistem pendidikan di Indonesia dalam pemaparan Ira di jurnalnya dalam pelajaran yang harus diikuti oleh siswa selain dirasakan terlalu padat juga tidak berkesinambungan, tidak konsisten, juga tidak sesuai dengan minat dan kebutuhan anak didik dan bahkan tidak cocok dengan kebutuhan pasar. Sulitnya mencari pekerjaan sering kali disebabkan bukan karena tidak ada pekerjaan atau sempitnya kesempatan berusaha, tetapi disebabkan karena tidak adanya kecocokan antara kemampuan yang diperoleh melalui sekolah dengan tuntutan atau syarat kerja (Ira, 2015). Dalam sistem pendidikan yang ada saat ini menyebabkan dampak yang 
dapat mendorong pengembangan potensis siswa, misalnya, perubahan kurikulum yang tidak mendasar, muatan materi kurikulum yang terlalu kompleks dan belum realistis, dan tuntutan kurikulum yang tidak memperhatikan kesesuaian dan potensi lokal yang dimiliki disetiap daerah.

Pada aspek pengembangan potensi, pendidikan saat ini berorintasi hanya pada kemampuan kognitif, belum dapat mengembangkan potensi siswa sesuai dengan kekuatan yang dimilikinya sehingga, mengabaikan kecerdasan yang lain, atau sering disebut dengan kecerdasan majemuk (multiple intelligence) yang dimiliki setiap siswa. Kemampuan kognitif merupakan hal yang penting dalam kehidupan seseorang, tetapi kemampuan ini bukan satu-satunya faktor penentu sukses atau tidaknya seseorang. Setiap individu memiliki sejumlah potensi berbeda yang diwarisi dari generasi kegenerasi yang merupakan faktor keturunan (heredity factor) sebagai kemampuan awal yang dimilikinya, dan semua potensi itu akan dapat berkembang dengan baik melalui stimulasi edukatif dan upaya-upaya dari lingkungan. Sehingga setiap siswa berbeda satu dengan yang lainnya, masing-masing siswa akan mengembangkan pengetahuan, sikap dan keterampilan dengan cara yang berbeda pula. Salah satu potensi bawaan yang dimiliki oleh siswa secara neurobiologi adalah otak. Spesialisasi fungsionalnya dapat mengarah pada pengembangan sifat-sifat manusia yang unik, seperti gaya belajar yang berbeda dan bahasa lisan, tulisan yang unik satu sama lain. Potensi bawaan ini sudah terbentuk sejak usia 10-12 minggu setelah masa konsepsi (conception phase).

Ciri-ciri luar biasa ini sangat bergantung pada sistem memori dan pengiriman fungsi kerja otak (Sousa, 2017). Bukti penelitian terus terkumpul mengenai area otak khusus. Bahkan otak bayi baru lahir prematur (kurang dari 30 minggu dalam rahim) menunjukkan area lateralisasi (Kwon et al., 2015). Akibatnya, ahli saraf harus memodifikasi teori mereka tentang organisasi otak. Para peneliti sekarang menawarkan gagasan bahwa otak adalah sekumpulan unit modular yang menjalankan tugas-tugas tertentu. Menurut model modular ini, otak adalah kumpulan unit yang mendukung persyaratan pemrosesan informasi pikiran (modul bahasa, modul kompetensi numerik, modul visual, dll.) Dan bukan unit tunggal yang setiap bagiannya mampu melakukan fungsi apa pun sendiri (Dwyer et al., 2014; van den Heuvel \& Sporns, 2013; Yamaguti \& Tsuda, 2015; Yang \& Shah, 2014). Hal tersebut menunjukkan adanya kecerdasan majemuk pada siswa berdasarkan fungsi kerja otak.

Data penelitian mendukung gagasan bahwa setiap belahan otak memiliki seperangkat fungsi sendiri dalam pemrosesan informasi dan pemikiran. Namun, fungsifungsi ini jarang berlaku eksklusif hanya untuk satu belahan, dan bahkan dalam beberapa tugas sederhana, kedua belahan bisa terlibat. Banyak tugas dapat dilakukan oleh salah satu belahan otak, meskipun salah satu mungkin berfungsi lebih maksimal. Ada keselarasan dalam tujuan masing-masing, dan saling melengkapi di hampir semua kegiatan. Dengan demikian, manfaat individu dari integrasi pemrosesan yang dilakukan oleh kedua belahan otak dapat diberikan pemahaman tentang situasi untuk memulai pemrosesan.

Mengetahui perbedaan antara bagaimana otak kiri dan kanan memproses informasi menjelaskan mengapa kita berhasil dengan beberapa tugas tetapi tidak dengan yang lain, terutama ketika kita mencoba melakukannya secara bersamaan. Otak mungkin menjadi faktor yang berkontribusi pada profil belajar individu, meskipun hanya ada sedikit bukti penelitian ilmu saraf sampai saat ini untuk mendukung gagasan ini. Kurangnya bukti substansial, tidak meniadakan pengamatan yang telah dilakukan oleh guru berpengalaman terhadap perilaku siswa yang menunjukkan cara berbeda, 
mereka menafsirkan pembelajaran siswa. Ketika guru memahami perbedaan ini, mereka merencanakan pelajaran yang membahas semua preferensi pembelajaran.

Menyadari bahwa pengorganisasian otak kemungkinan besar merupakan kontributor preferensi pembelajaran, muncul pertanyaan apakah iklim sekolah dan instruksi kelas dirancang untuk merangkul preferensi yang berbeda sehingga semua peserta didik dapat berhasil. Mungkinkah sekolah dirancang secara tidak sengaja untuk mendukung satu jenis preferensi belajar daripada yang lain? Sekolah Berorientasi Bahasa, sebagian besar pendidik mengakui bahwa sekolah sebagian besar adalah lembaga yang berorientasi pada bahasa, terutama di sekolah dasar. Pelajar yang mahir bahasa (terutama perempuan) merasa lebih nyaman di lingkungan ini. Semakin kuat keterampilan bahasa mereka, semakin sukses pembelajar ini. Sebaliknya, pelajar dengan kemampuan visual dan spasial (terutama anak laki-laki) merasa tidak nyaman; dan semakin kuat keterampilan ini, lingkungan belajar tampaknya semakin tidak ramah. Ini dapat menjelaskan mengapa kebanyakan guru mengakui bahwa mereka memiliki lebih banyak masalah disiplin dengan anak laki-laki daripada dengan anak perempuan. Mungkin apa yang dikatakan penelitian ini adalah bahwa anak laki-laki (lebih tepatnya, pelajar visual dan spasial yang kuat) tidak dilahirkan dengan "gen jahat", tetapi mereka terlalu sering ditempatkan di lingkungan belajar yang tidak nyaman di mana mereka bereaksi memberontak.

Instruksi yang dibedakan seorang pendidik harus mengenali bahwa otak perempuan dan laki-laki muda tidak matang pada saat yang bersamaan. Lebih banyak anak laki-laki, yang kemudian berhasil di sekolah dapat mengenali gaya belajar yang berbeda dan sesuai dengan instruksi individual. Semua siswa akan mencapai lebih banyak ketika guru dengan sengaja merencanakan strategi mengajar ke seluruh otak dengan mengatasi kekuatan dan kelemahan dari kedua jenis kelamin. Tampaknya kekuatan sosial dan budaya memiliki pengaruh besar. Anak laki-laki di sekolah menengah didorong oleh orang tua dan guru mereka untuk mengambil lebih banyak matematika dan sains, pengalaman mereka di kelas semacam itu lebih sesuai dengan kemampuan visual dan spasial mereka, dan dengan demikian mereka mendapat nilai lebih baik pada tes di bidang ini. Anak perempuan, di sisi lain, sering menemukan stereotip yang menganggap perempuan berkinerja buruk dalam matematika, dan dengan demikian kurang berhasil dalam sains. Penelitian telah mengungkapkan bahwa kinerja perempuan dalam tes matematika lebih rendah daripada laki-laki hanya karena adanya stereotip ini, yang disebut ancaman stereotip, dan kinerja perempuan meningkat setelah ancaman stereotip dihilangkan (Deemer, Thoman, Chase, \& Smith, 2014; Rydell, Van Loo, \& Boucher, 2014).

Kabar baiknya adalah kesenjangan gender itu sempit. Persentase anak perempuan yang mengambil berbagai mata pelajaran matematika dan sains mendekati atau melebihi persentase anak laki-laki, dan nilai ujian anak perempuan pada rata-rata nasional hanya beberapa poin lebih rendah dan tidak signifikan secara statistik (Pusat Statistik Pendidikan Nasional, 2014). Ini adalah tren yang menggembirakan. Sebagian, penjelasan untuk hasil ini mungkin adalah penggunaan komputer dan teknologi lain di dalam kelas. Baik anak laki-laki maupun perempuan berada di lapangan bermain yang setara. Pelajaran komputer tidak terkait erat dengan keberhasilan atau kegagalan masa lalu, mewakili seperangkat keterampilan baru yang dipelajari oleh anak laki-laki dan perempuan pada usia yang sangat dini. Selain itu, komputer dan teknologi terkait bersifat sabar dan menyenangkan, berkontribusi pada kebaruan dan pemenuhan harapan akan kesuksesan. 
Tugas kita sekarang adalah memastikan bahwa pendidik dan orang tua mengetahui bahwa anak laki-laki mungkin memiliki beberapa preferensi belajar yang berbeda dari anak perempuan, tetapi kedua jenis kelamin memiliki kemampuan yang sama untuk berhasil dalam matematika dan sains. Untuk itu, kita perlu mengekang kekuatan budaya dan sosial yang akan memberi pengaruh stereotip masa lalu tentang apakah siswa dari jenis kelamin tertentu hanya boleh mengambil mata pelajaran tertentu. Ada banyak bukti bahwa ketika anak perempuan didorong dan dimotivasi, mereka dapat unggul dalam sains dan matematika (Flore \& Wicherts, 2015). Perlu diulang di sini bahwa studi ilmiah memberi tahu kita tentang rata-rata dalam kelompok dan tidak ada apa pun tentang bagaimana individu tertentu akan berhasil atau gagal dalam bidang subjek apa pun.

Guru di Sekolah dasar sebagai fasilitator dan sumber belajar saat ini belum memahami secara mendalam tentang fungsi otak dalam belajar, sehingga belum optimal menstimulasi tumbuh kembang otak dan fungsinya. Padahal guru memiliki peranan yang penting dalam membantu, membimbing dan mentransfer pengetahuan. Secara harfiah penjelasan dari Arifmiboy di dalam jurnalnya guru memiliki peranan yang sangat strategis terutama dalam membentuk watak bangsa serta mengembangkan potensi siswa. Kehadiran guru tidak tergantikan oleh unsur yang lain, lebih-lebih dalam masyarakat kita yang multikultural dan multidimensional, dimana peranan teknologi untuk menggantikan tugas-tugas guru sangat minim (Arifmiboy, 2016). Guru memiliki peranan yang sangat penting dalam menentukan keberhasilan pendidikan. Guru yang profesional diharapkan menghasilkan lulusan yang berkualitas. Profesionalisme guru sebagai ujung tombak di dalam implementasi kurikulum di kelas yang perlu mendapat perhatian. Larlen memberikan ulasan dalam jurnal nya yaitu Dalam proses belajar mengajar, guru mempunyai tugas untuk mendorong, membimbing, dan memberi fasilitas belajar bagi siswa untuk mencapai tujuan (Larlen, 2013). Wawasan dari astriani menjelaskan guru memiliki peranan yang sangat strategis terutama dalam membentuk watak bangsa serta mengembangkan potensi siswa. Kehadiran guru tidak tergantikan oleh unsur yang lain, lebih-lebih dalam masyarakat kita yang multikultural dan multidimensional, dimana peranan teknologi untuk menggantikan tugas-tugas guru sangat minim. Guru memiliki peranan yang sangat penting dalam menentukan keberhasilan pendidikan. Guru yang profesional diharapkan menghasilkan lulusan yang berkualitas (Astriani, 2017).

Profesionalisme guru sekolah dasar merupakan ujung tombak di dalam implementasi pembelajaran di kelas sesuai dengan kurikulum nasional dan kebutuhan siswa. Dalam proses belajar mengajar, guru mempunyai tugas untuk mendorong, membimbing, dan memberi fasilitas belajar bagi siswa untuk mencapai tujuan. Guru mempunyai tanggung jawab untuk melihat segala sesuatu yang terjadi dalam kelas untuk membantu proses perkembangan siswa laki-laki maupun perempuan dengan berupaya mengembangkan kecerdasan majemuk pada siswa. Penyampaian materi pelajaran hanyalah merupakan salah satu dari berbagai kegiatan dalam belajar sebagai suatu proses yang dinamis dalam segala fase dan proses perkembangan siswa. Dengan demikian perlunya kemampuan Guru dalam menerapkan strategi untuk mengoptimalkan kecerdasan majemuk di Sekolah Dasar.

\section{METODE}

Metode yang digunakan dalam penelitian ini adalah kajian literatur. Kajian literatur adalah satu penelusuran dan penelitian kepustakaan dengan membaca dan 
menganalisis berbagai buku, jurnal, dan terbitan-terbitan lain yang berkaitan dengan topik penelitian, untuk menghasilkan satu tulisan berkenaan dengan satu topik atau isu tertentu (Marzali, 2016). Adapun langkah-langkah penelitian kepustakaan yang akan dilakukan dalam penelitian ini (Loe, 2017), meliputi;1) bagian pendahuluan, 2) bagian utama, 3) kesimpulan. Sumber data penelitian ini diperoleh dari literatur-literatur yang relevan seperti buku, artikel ilmiah atau jurnal yang terkait dengan topik yang dipilih. Teknik pengumpulan data yang digunakan dalam metode study literature atau penelitian kepustakaan ini yaitu mencari data mengenai hal-hal atau variabel yang berupa catatan, buku, makalah atau artikel, jurnal dan sebagainya (Santosa, 2015).

Teknik analisis data yang digunakan berupa analisis isi. Pembacaan pustaka secara berulang dan pengecekan antar pustaka dilakukan agar menjaga ketepatan pembahasan dan mencegah kesalahan informasi dalam analisis data. (kesalahan pengertian manusiawi yang bisa terjadi karena kurangnya pengetahuan peneliti atau kurangnya penulis pustaka). Penelitian ini dilaporkan dengan menyusun hasil penemuan berdasarkan prinsip kemudahan dan kesederhanaan. Hal ini mengingat peneliti memiliki keterbatasan kemampuan yang belum mampu melakukan kajian pustaka secara mendalam dan lebih detail. Selain itu, kesederhanaan dan kemudahan dalam penyampaian hasil dibuat agar mempermudah pembaca dalam memahami inti isi mengenai strategi guru dalam mengembangkan multiple intelegence di Sekolah Dasar.

\section{HASIL DAN PEMBAHASAN \\ Hasil}

Kegiatan pengembangan berdasarkan multiple intelligences memberikan peluang keberhasilan yang lebih besar karena siswa mendapatkan kesempatan untuk belajar melalui cara-cara yang lebih bervariasi. Siswa akan berusaha mencapai hasil belajar yang optimal melalui cara yang sesuai dengan diri dan karakteristik objek yang dipelajari. Belajar tentang alam tentu berbeda dengan belajar tentang diri sendiri, kemanusiaan, dan musik. Siswa juga memiliki berbagai cara untuk belajar tentang objek. Tujuan belajar bagi setiap orang adalah memahami apa yang akan di pelajari melalui berbagai cara. Jeannette Vos, 2003 menguraikan pendapat para ahli tentang 12 cara anak belajar berikut ini:

Tabel 1. Cara Anak Belajar

\begin{tabular}{|c|c|}
\hline No & Kegiatan \\
\hline 1. & $\begin{array}{l}\text { Anak belajar melalui pengalaman melakukan aktivitas (learning by } \\
\text { doing). }\end{array}$ \\
\hline 2. & $\begin{array}{l}\text { Anak belajar melalui apa yang dilihat dan didengar (reinforce with picture } \\
\text { and sounds). }\end{array}$ \\
\hline 3. & Belajar harus menyenangkan bagi anak (learning should be fun). \\
\hline 4. & $\begin{array}{l}\text { Anak belajar harus berada pada situasi yang santai tetapi menantang } \\
\text { (learn in a relaxed but challenging situation). }\end{array}$ \\
\hline 5. & Belajar melalui musik dan ritme (learn with music and rhythm). \\
\hline 6. & $\begin{array}{l}\text { Belajar melalui penyatuan gerak tubuh dan aktivitas otak (learn with lots } \\
\text { of movement-use the body and the mind together). }\end{array}$ \\
\hline 7. & $\begin{array}{l}\text { Belajar dengan saling berbicara dengan yang lain atau berkomunikasi } \\
\text { (learning by talking to each other). }\end{array}$ \\
\hline 8. & Belajar dengan refleksi (learn by reflecting). \\
\hline 9. & Belajar melalui integrasi angka dan kata secara menyenangkan (link \\
\hline
\end{tabular}




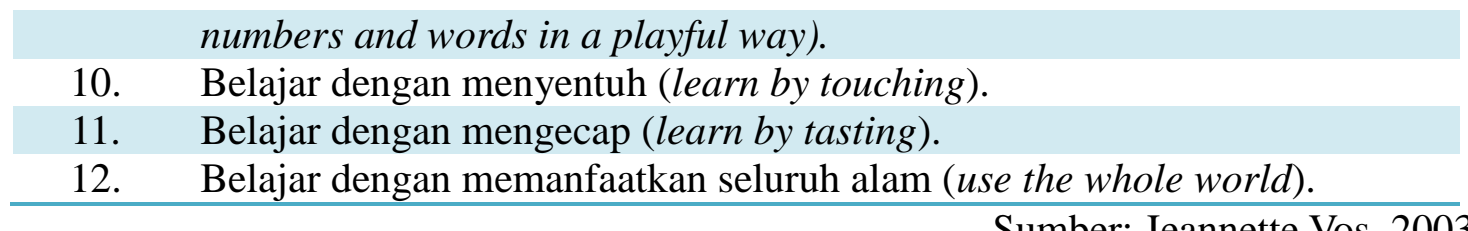

Berdasarkan gambaran tabel di atas, dapat disimpulkan bahwa siswa belajar dengan berbagai cara. Cara-cara tersebut memungkinkan anak menguasai berbagai pengetahuan sesuai dengan karakteristik pengetahuan yang akan dipelajarinya. Pengetahuan mengenai rasa membutuhkan ketajaman pengecapan, tekstur dengan perabaan. Hal yang juga sangat penting adalah bahwa belajar harus berada pada situasi yang menyenangkan, relaks, tapi menantang. Belajar harus menyatukan gerakan tubuh dan gerakan pikiran. Pendapat para ahli tentang bagaimana siswa belajar sangat sesuai dengan konsep multiple intelligences. Menurut (Armstrong ,1996). Peran guru yang professional bervisi tentang kelas sebagai mikrokosmis masyarakat sejalan dengan konsep multiple intelligences dalam hal teknik pembelajaran. Artinya, apa yang diberikan di kelas, harus memberikan kontribusi terhadap kehidupan nyata siswa di masyarakat. Apa yang dipelajari siswa bukanlah sesuatu yang lepas dari kehidupan sosial. Selain itu, anak harus belajar dengan beraktivitas. Aktivitas inilah yang menimbulkan pengalaman dan menstimulasi kecerdasan.

Teori multiple intelligences membuka kemungkinan bagi setiap siswa untuk belajar dan mencapai tugas perkembangan. Multiple intelligences menghindarkan anak dari kegagalan tugas perkembangan, seperti rasa rendah diri dan tidak bahagia, rasa ketidaksetujuan dan penolakan sosial, yang akan menyulitkan penguasaan tugas perkembangan baru. Tugas perkembangan akan terganggu jika anak tidak memperoleh kesempatan untuk belajar apa yang diharapkan oleh kelompok sekolah, tidak memperoleh bimbingan dalam belajar, dan tidak memiliki motivasi untuk belajar. Sebaliknya anak akan terdukung oleh lingkungan yang memberikan kesempatan anak untuk belajar, bimbingan belajar dari orang tua dan pendidik, serta motivasi yang kuat untuk belajar. Hal ini berarti, multiple intelligences memberi kesempatan pada anak untuk mendapatkan dukungan untuk pencapaian tugas perkembangan.

\section{Kecerdasan}

\section{Pembahasan}

Kecerdasan atau yang biasa disebut dengan inteligensi berasal dari bahasa Latin "intelligence" yang berarti menghubungkan atau menyatukan satu sama lain (to organize, to relate, to bind together). Dalam jurnal Tanjung dipaparkan bagi para ahli yang meneliti, istilah inteligensi memberikan bermacam-macam arti. Menurut mereka, kecerdasan merupakan sebuah konsep yang bisa diamati tetapi menjadi hal yang paling sulit untuk didefinisikan. Hal ini terjadi karena inteligensi tergantung pada konteks atau lingkungannya. Tokoh pengukuran inteligensi mengatakan bahwa kecerdasan adalah kemampuan yang terdiri dari tiga komponen, yakni (1) kemampuan untuk mengarahkan pikiran atau tindakan, (2) kemampuan untuk mengubah arah pikiran atau tindakan, dan (3) kemampuan untuk mengkritisi pikiran dan tindakan diri sendiri atau autocritism. (Tanjung, 2018). Kecerdasan merupakan sesuatu yang fungsional sehingga tingkat perkembangan individu dapat diamati dan dinilai berdasarkan kriteria tertentu. Apakah seorang siswa cukup inteligen atau tidak, dapat dinilai berdasarkan pengamatan 
terhadap cara dan kemampuan anak melakukan tindakan dan kemampuan mengubah arah tindakan apabila diperlukan.

\section{Konsep Multiple Intelligences}

Menurut Garner dalam buku nya setiap individu mempunyai kecerdasan majemuk. Kecerdasan majemuk adalah suatu kemampuan untuk memecahkan masalah atau menghasilkan sesuatu yang dibutuhkan di dalam latar budaya tertentu. Menurutnya faktor-faktor yang mempengaruhi kecerdasan seseorang adalah faktor pengalaman, lingkungan atau pembentukan, kemauan dan keputusan, bawaan, gaya hidup, aktifitas belajar dan kegiatan harian, kematangan dan kebebasan berfikir. Disamping itu juga dikemukanannya beberapa pokok pikirannya yaitu: (1) Manusia mempunyai kemampuan meningkatkan dan memperkuat kecerdasannya, (2) Kecerdasan selain dapat berubah dapat pula diajarkan kepada orang lain, (3) Kecerdasan merupakan realitas majemuk yang muncul di bagian-bagian yang berbeda pada sistem otak atau pikiran manusia, dan (4) Pada tingkat tertentu, kecerdasan ini merupakan suatu kesatuan yang utuh (Howard Gardner, 2003). Artinya dalam memecahkan masalah atau tugas tertentu, seluruh macam kecerdasan manusia bekerja bersama-sama, kompak dan terpadu.

Para guru dan orang tua sering kali berpikir bahwa anak yang cerdas adalah anak yang pintar dalam bidang science, seperti matematika, IPA, kimia dan teknologi. Sementara orang yang berprestasi di bidang seni dan olah raga, seperti pelukis, atlet, penyair, dan prestasi lain sering dipandang sebelah mata. Pada kenyataannya, kita tidak dapat mengingkari bahwa banyak orang sukses di dunia ini yang tidak berhasil secara akademis. Untuk mengembangkan kecerdasan seorang anak, diperlukan tiga kebutuhan pokok, yaitu kebutuhan fisik, emosi, dan stimulasi dini. Hal inilah yang mesti terpenuhi sehingga delapan kecerdasan tersebut dapat dioptimalkan. Untuk lebih jelasnya mari kita kenali delapan kecerdasan jamak tersebut lebih dekat: Seorang ahli pendidikan dari Harvard University bernama Howard Gardner berpendapat bahwa tidak ada manusia yang tidak cerdas. Paradigma ini menentang teori dikotomi cerdas-tidak cerdas. Gardner juga menentang anggapan "cerdas" dari sisi IQ (intelectual quotion), yang menurutnya hanya mengacu pada tiga jenis kecerdasan, yakni logiko-matematik, linguistik, dan spasial. Untuk selanjutnya, Howard Gardner, kemudian memunculkan istilah multiple intelligences. Istilah ini kemudian dikembangkan menjadi teori melalui penelitian yang rumit, melibatkan antropologi, psikologi kognitif, psikologi perkembangan, psikometri, studi biografi, fisiologi hewan, dan neuroanatomi (Armstrong, 1993).

Bagi para pendidik dan implikasinya bagi pendidikan, teori multiple intelligences melihat anak sebagai individu yang unik. Pendidik akan melihat bahwa ada berbagai variasi dalam belajar, di mana setiap variasi menimbulkan konsekuensi dalam cara pandang dan evaluasinya. Kecerdasan, menurut paradigma multiple intelligences (Gardner, 1993) dapat didefinisikan sebagai kemampuan yang mempunyai beberapa komponen yakni:

1. Kecerdasan Linguistik/Bahasa

Kecerdasan verbal-linguistik adalah kemampuan untuk menggunakan bahasa, yang termasuk bahasa ibu dan bahasa asing untuk mengekspresikan apa yang ada di dalam pikiran dan memahami orang lain (Baum,Viens, dan Slatin, 2005). Kecerdasan lingusitik disebut juga kecerdasan verbal karena mencakup kemampuan untuk mengekspresikan diri secara lisan dan tertulis, serta kemampuan untuk menguasai bahasa asing (Mc Kenzie, 2005) Berikut ini karakteristik individu yang 
menunjukkan kemampuan dalam intelegensi bahasa; (a) Senang membaca buku, bercerita atau mendongeng, (b) Senang berkomunikasi, berbicara, berdialog, berdiskusi, dan senang berbahasa asing, (c) Pandani menghubungkan atau merangkaikan kata-kata atau kalimat baik lisan ataupun tertulis, (d) Pandai menafsirkan kata-kata atau paragraph baik secara lisan maupun tertulis, (e) Senang mendengarkan musik dan sebagainya dengan baik, (f) Pandai mengingat dan menghafal, (g) Humoris. Contoh orang-orang yang memiliki kecerdasan bahasa yaitu: pengarang, penyair, wartawan, pembicara, pembaca berita dll. Kecerdasan ini dapat menunjukkan kecerdasan logika berpikir seorang siswa. Jika dia bisa berbahasa atau berbicara dengan bagus dan lancar niscaya logika berpikirnya akan bagus. Siswa cenderung lebih sering menggunakan kata-kata yang acak-acakan.

Peran guru dalam kecerdasan bahasa dalam merangsang siswa, sebaiknya guru sering mengajak siswa berbincang, membacakan cerita atau dongeng, dan mengajarkan nyanyian atau lagu. Pandai berbahasa bukan hanya berarti menguasai banyak bahasa, melainkan siswa mempunyai kemampuan dalam mengolah bahasa. Hal ini penting untuk mengajarkan bahasa ibu terlebih dahulu karena hal itu akan mendorong logika berpikir siswa. Tidak semua siswa cerdas dalam berbahasa. Seandainya siswa belum siap menerima multibahasa, jangan memberikannya. Bila guru dan orangtua memaksa siswa dengan beragam bahasa, hasilnya siswa akan mengalami kebingungan bahasa. Stimulus dari lingkungannya akan mempengaruhi kemampuan otak siswa dan pada akhirnya akan bermuara pada keterampilan siswa dalam mengolah kata-kata dan berbicara. Biasanya, kurangnya kemampuan berbahasa pada siswa terjadi apabila sejak kecil anak jarang diajak berkomunikasi.

2. Kecerdasan Logika Matematika

Kecerdasan matematik adalah kemampuan yang berkenaan dengan rangkaian alasan mengenal pola-pola dan aturan. Kecerdasan ini merujuk kepada kemampuan mengeksporasi pola-pola, kategori-kategori, dan hubungan dengan memanipulasi objek atau symbol untuk melakukan percobaan dengan cara yang terkontrol dan teratur (Kanzer, 2001). Seseorang yang memiliki kecerdasan logis matematis memungkinkan terampil dalam melakukan hitungan, penghitungan atau kuantifikasi, mengemukakan proposisi dan hipotesis dan melakukan operasi matematis yang kompleks. Berikut ini karakteristik individu menurut Gardner yang menunjukkan kemampuan dalam inteligensi logismatematis: (a) Senang bereksperimen, bertanya, menyusun atau merangkai teka - teki, (b) Senang dan pandai berhitung dan bermain angka, (c) Senang mengorganisasikan sesuatu, menyusun scenario, (d) Mampu berfikir logis baik induktif maupun deduktif, (e) Senang silogisme, (f) Senang berfikir abstraksi dan simbolis. Contoh-contoh orang yang memiliki kecerdasan matematis logis adalah ilmuwan, matematikawan, akuntan, insinyur, dan pemprogram computer. Biasanya logika matematika dikatikan dengan otak yang melibatkan beberapa komponen, yakni perhitungan secara matematis, berpikir logis, dan pemecahan masalah. Anak dengan kemampuan ini akan senang berkutat dengan rumus-rumus dan pola-pola abstrak. Tidak hanya pada bilangan matematika, tetapi juga meningkat pada kegiatan yang bersifat analisis dan konseptual. Ada kaitan antara logika matematika dan kecerdasan linguistik, anak menganalisis dan menjabarkan alasan logis, serta kemampuan mengonstruksi solusi dari persoalan yang timbul (Gardner, 1993). Ciri anak yang cerdas matematika adalah anak yang suka mengotak-atik benda dan melakukan uji coba. 
Dalam hal ini guru dituntut untuk kreatif dalam mengenalkan dan mengajarkan konsep matematika sehingga siswa menjadi happy dalam mempelajarinya dan tidak menganggap matematika sebagai sesuatu yang menakutkan. Beberapa cara guru dalam membantu anak mengembangkan kecerdasan matematika, diantaranya (1) Perbanyak koleksi buku-buku referensi mengenai konsep matematika, (2) Buat permainan seru dengan melibatkan murid-murid dalam lomba-lomba, seperti berhitung dan permainan asyik lainnya, dan (3) Manfaatkan berbagai benda yang ada di sekitar kita sebagai media pengajaran. Misalnya, saat mengajarkan bangun ruang atau datar dan lingkaran, mintalah anak untuk mengamati pola dari beberapa bendera negara dari buku-buku, bentuk atap rumah dan sebagainya.

3. Kecerdasan Gerak Kecerdasan jasmaniah-kinestetik

Kemampuan untuk menggunakan seluruh tubuh dalam mengeksperisikan ide perasaan, dan menggunakan tangan untuk menghasilkan atau mentransformasikan sesuatu. Kecerdasan ini mencakup keterampilan khusus seperti, koordinasi, keseimbangan, ketangkasan, kekuatan, fleksibilitas, dan kecepatan. Kecerdasan ini juga meliputi keterampilan untuk mengontrol gerakangerakan tubuh dan kemampuan untuk memanipulasi objek (Sonawat and Gogri, 2008). Senada dengan pernyataan di atas, Howard Gardner (1999:12), mengatakan bahwa kecerdasan jasmaniah adalah: "the capcity to use your whole body or parts of your body-your hands, your fingers, and your arms - to solve a problem, make something, or put on some kind of a production. The most evident examples are people in athletics or the performing arts, particularly dance or acting". Contoh-contoh orang yang memiliki kecerdasan kinestetik yaitu atlet, penari, ahli bedah, dan pengrajin. Berikut ini individu yang menunjukkan kemampuan dalam inteligensi kinestetik tubuh: (a) Senang menari atau acting, (b) Pandai dan aktif dalam olahraga tertentu, (c) Mudah berekspresi dengan tubuh, (d) Mampu memainkan mimic, (e) Koordinasi dan fleksibilitas tubuh tinggi, (f) Senang dan efektif berfikir sambil berjalan, berlari dan berolahraga, (g) Pandai merakit sesuatu menjadi suatu produk, (h) Senang bergerak atau tidak bisa diam dalam waktu yang lama, dan (i) Senang kegiatan di luar rumah. Dengan demikian kecerdasan kinestetik disebut juga kecerdasan olah tubuh karna dapat merangsang kemampuan seseorang untuk mengolah tubuh secara ahli, atau untuk mengekspresikan gagasan dan emosi melalui gerakan. Kemampuan seperti ini dapat diamati pada anak yang pandai berolah raga, menari, atau acting.

Kecerdasan gerak merupakan kemampuan seseorang untuk mengekspresikan ide dan perasaan dalam gerakan tubuh. Kecerdasan ini dimiliki orang-orang yang menggunakan koordinasi tubuhnya dan mampu mengontrol gerakan-gerakannya itu, seperti para atlet dan penari. Anak yang menonjol dalam hal ini sering disebut body smart. Umumnya, anak cerdas gerak memiliki kematangan motorik, baik motorik kasar, seperti berlari, menangkap, melempar, dan memanjat tebing, maupun motorik halus, seperti menulis, menggunting, dan menempel. Keduat tipe gerakan ini membutuhkan koordinasi visual-motorik, ketepatan, keseimbangan, dan kelenturan. Komponen inti dari kecerdasan kinestetik bertumpu pada kemampuankemampuan fisik yang spesifik, seperti koordinasi, keseimbangan, keterampilan, kekuatan, kelenturan, dan kecepatan maupun kemampuan menerima atau merangsang dan hal yang berkaitan dengan sentuhan. Kemampuan ini juga merupakan kemampuan motorik halus, kepekaan sentuhan, daya tahan dan reflex (Richey, 2007).

Guru dapat membantu orangtua menemukan dan mengembangkan kecerdasan gerak anak sejak dini. Kecerdasan ini dapat diamati saat siswa mulai melakukan 
gerak bertujuan, misalnya berjalan, melompat, memanjat, atau berlari. Bila anak terlihat mampu melakukan gerakan dengan sangat terampil dibandingkan dengan anak seusianya, berarti ada kemungkinan dia memiliki kelebihan dalam kecerdasan gerak. Melalui aktivitas olahraga atau seni, seperti menyanyi atau menari, anak dapat teramati kemampuan geraknya. Kecerdasan gerak tidak sekedar melibatkan gerakan saja, tapi juga melibatkan kemampuan berpikir. Misalnya, meniru gerakan tarian atau menendang bola ke arah gawang. Beberapa kegiatan yang bisa dilakukan untuk mengembangkan potensi siswa yang tergolong cerdas gerak, antara lain: (1) Memberikansiswa ruang yang cukup untuk bergerak sehingga siswa cerdas gerak berlajar berinteraksi dengan ruang di sekitarnya, (2) Minta siswa untuk berpartisipasi dalam aktivitas yang berorientasi pada gerakan, seperti pementasan drama dan menari dalam kegiatan sekolah, senam, balet, dan olahraga. Beberapa aktivitas menawarkan siswa belajar melalui interaksi spasial dan gerakan tubuh yang bermanfaat untuk membangun kepercayaan dirinya, (3) Melakukan beberapa kegiatan yang menunjang kemampuan gerak motorik anak, seperti memasukkan manik-manik ke benang, menggunting kertas, dan kegiatan kerajinan tangan (4) Bermain petak umpet, kucing-kucingan, lompat tali, dan sebagainya. Banyak orang tua yang kemudian mengarahkan anaknya untuk mengikut les-les yang bisa mengembangkan kecerdasan gerak anaknya, seperti les menari, renang dan sebagainya. Sayang, anak sering cepat bosan dengan aktivitasnya. Di sinilah peran guru dan orang tua dituntut untuk jeli memilih kegiatan yang tidak hanya berfokus pada pengembangan keterampilan geraknya, tetapi juga harus bisa mengembangkan kecerdasan-kecerdasan lainnya.

4. Kecerdasan Spasial

Kecerdasan visual-spasial merupakan kecerdasan yang berkaitan dengan bakat seni, khususnya seni lukis dan seni arsitektur. Orang yang memiliki kecerdasan spasial adalah orang yang memiliki kapasitas dalam berfikir secara tiga dimensi (Snawat dan Gogri, 2008). Contoh-contoh orang yang memiliki kecerdasan spasial adalah pelaut, pilot, pematung, pelukis daan arsitek. Kecerdasan spasial memungkinkan individu dapat mempersepsikan gambar-gambar baik internal maupun eksternal dan mengartikan atau mengkomunikasikan informasi grafis. Berikut ini karakteristik individu yang menunjukkan kemampuan dalam inteligensi visual spasial: (a) Senang merancang sketsa, gambar, desain grafik dan table, (b) Peka terhadap citra, warna dan sebagainya, (c) Pandai menvisualisasikan ide, (d) Imaginasinya aktif, (e) Mudah menemukan jalan pada ruang, (f) Mempunyai presepsi yang tepat dari berbagai sudut, dan (g) Mengenal relasi benda - benda dalam ruang. Kecerdasan ini melibatkan imajinatif aktif yang membuat seseorang mampu mempersepsikan warna, garis dan luas, serta menetapkan arah dengan tepat. Kecerdasan spasial umumnya dimiliki para pelukis, pemahat, arsitek, dan pilot. Anak dengan kecerdasan spasial-visual adalah pengamat dunia. Mereka peka terhadap tanda-tanda alam dan mengamatinya secara menyeluruh. Siswa dengan tipe kecerdasan seperti ini biasanya menyukai pelajaran yang dikemas dalam metode diagram, grafik, tabel, dan mind mapping.

Lalu bagaimana cara mengembangkan kecerdasan spasialvisual siswa? a) Guru dapat mengajarkannya mengenal arah dengan mulai membedakan tangan kanan dan kiri atau kaki kanan dan kiri. Jika siswa sudah paham, saat jalan pulang ke rumah tanyakan, Jalan pulang belok kanan atau belok kiri, ya? b) Bermain puzzle dan balok, Sebaiknya jumlah puzzle disesuaikan dengan usia dan kemampuan siswa. 
Saat anak berusia 3 tahun, cobalah lima keping puzzle dulu. Semakin usia bertambah jumlah puzzle pun bertambah. Begitupun dengan bermain balok; semakin bertambah usianya lebih tinggi pula tingkat kesulitannya. c) Belajar bentuk, Saat anda membaca buku bersama anak didik, mintalah dia memperhatikan bentuk-bentuk rumah, bola, atau benda yang ada dalam buku. Sebutkan konsep garis, seperti melengkung, lurus, zig-zag, bulat, persegi, atau kerucut. Deskripsikan suatu bentuk secara verbal, lalu mintalah anak menggambarkannya. Kemudian ajaklah anak berlatih membentuk berbagai gambar dari sebuah garis lurus atau lengkung. Peran guru dalam hal ini bertujuan untuk melatih siswa dalam menerjemahkan suatu bentuk ke dalam pikirannya menjadi gambar dua dimensi. Kegiatan mewarnai juga dapat melatih siswa mengenal batasan posisi warna merah atau kuning supaya tidak melewati garis. Sekali-kali tanyakan kepada anak didik, dari sebuah garis lengkung atau titik, bisa menjadi gambar apa, ya? Jika jawabannya lebih dari tiga, bisa jadi anak didik kita memiliki daya imajinasi bentuk dan ruang yang meyakinkan.

5. Kecerdasan Musical

Kecerdasan musik adalah kapasitas berfikir dalam music untuk mampu mendengarkan pola-pola dan mengenal, serta mungkin memanipulasinya. Orang yang memiliki kecerdasan music yang kuat tidak saja mengingat music dengan mudah, mereka tidak dapat keluar dari pemikiran music dan selalu hadir di manamana. Kecerdasan musikal diartikan sebagai kemampuan menangani bentuk musik yang meliputi (1) kemampuan mempersepsi bentuk musical seperti menagkap atau menikmati music dan bunyi-bunyi berpola nada, (2) kemampuan membedakan bentuk music, seperti membedakan dan membandingkan ciri bunyi music, suara, dam alat music, kemampuan mengubah bentuk music seperti mencipta dan memversikan music, dan (4) kemampuan mengekspresikan bentuk music seperti bernyanyi, bersenandung, dan bersiul-siul (Snyder, 1997). Kecerdasan musikal dibuktikan dengan adanya rasa sensitif terhadap nada, melodi, irama musik.

Orang-orang yang memilki kecerdasan musikal yang baik antara lain; komposer, konduktor, musisi, kritikus musik, pembuat instrumen dan orang-orang sensitif terhadap unsur suara. Berikut ini karakteristik individu yang menunjukkan kemampuan dalam inteligensi musikal: (a) Pandai mengubah atau mencipta music, (b) Senang dan padai bernyanyi, (c) Pandai mengoperasikan musik serta menjaga ritme, (d) Mudah menangkap music, dan (e) Peka terhadap suara dan musik. Hal ini berarti, kecerdasan musical meliputi kemampuan mempersepsi dan memahami, mencipta dan menyanyikan bentuk-bentuk musical. Para ahli mengakui bahwa music merangsang aktivitas kognitif dalam otak dan mendorong kecerdasan. Musik adalah bahasa universal atau musik sebagai ekspresi diri. Ia merupakan pernyataan untuk melukiskan betapa musik mewarnai kehidupan manusia dan dapat diterima di belahan mana pun di dunia. Meskipun dapat dikatakan bahwa semua orang suka musik, ternyata tidak banyak yang memahami dan memiliki kecerdasan musik. Tipe kecerdasan ini berkembang sangat baik pada musisi, penyanyi dan komposer.

Kecerdasan bermusik mencakup kepekaan atau penguasaan terhadap nada, irama, polapola, ritme, tempo, instrumen, dan ekspresi musik sehingga seseorang mampu menyanyikan lagu, memainkan musik, dan menikmati musik. Imitasi dan eksplorasi terhadap berbagai bunyi, gambar, dan gerakan, selayaknya menjadi bagian dari pengalaman anak sehari-hari. Musik tidak hanya berkaitan dengan perkembangan kognitif, tapi juga mampu mengembangkan kecakapan sikap, 
tingkah laku, dan disiplin anak. Melalui musik, rasapercaya diri anak meningkat, yang kemudian menular ke bidang lainnya, seperti matematika, geografi, ekonomi dan sebagainya. Mengenali bakat musik pada anak didik dapat dilakukan melalui alat-alat musik yang mereka mainkan dan lagu-lagu yang dinyanyikan.

Pengenalan musik terhadap siswa di sekolah bisa dilakukan dengan cara membuat permainan-permainan menciptakan musik, misalnya dengan alat-alat makan (piring, sendok, atau gelas). Hal ini dapat membantunya mempelajari irama, lemah kuatnya nada, dan tinggi-rendahnya bunyi. Peran guru yang bisa dilakukan di sekolah untuk menggali kecerdasan musik anak didi antara lain: (1) Kenalkan siswa lewat berbagai jenis alat musik meskipun hanya lewat gambar, (2) Menyediakan alat-alat musik sederhana, misalnya gitar, drum, piano, tamborin mainan (dari plastik) dan sebagainya, (3) Mengajarkan not balok lewat lagu-lagu sederhana, (4) Untuk melatih kepekaan nada, anak juga dapat diperdengarkan lagu-lagu dengan irama yang berbeda saat dia makan, menggambar, bermain, dan dalam melakukan aktivitas lainnya, (5)Anak-anak cenderung menyukai lagu yang bernada riang. Bernyanyi bisa dikombinasikan dengan kegiatan bermain lainnya, seperti permainan kursi putar, dan (6) Ajaklah anak untuk menampilkan kebolehan mereka dalam acara-acara sekolah.

6. Kecerdasan Intrapersonal

Kecerdasan ini merupakan kemampuan seseorang untuk mengenali dan mengembangkan potensi, serta mengekspresikan dirinya. Komponen inti dari kecerdasan intrapersonal adalah kemampuan memahami diri yang akurat meliputi kekuatan dan keterbatasan diri, kecerdasan dan suasana hati, maksud, motivasi, termpramendan keinginan, serta kemampuan mendisiplinkan dari, memahami dan menghargai diri. Kemampuan mengahargai diri juga berarti mengetahui siapa dirinya, apa yang dapat dan ingin dilakukan, bagaimana reaksi diri terhadap situasi tertentu dan menyikapinya serta kemampuan dalam mengintrospeksi diri (Muhammad Yaumi, 2012) Seorang anak yang memiliki kecerdasan ini akan mengetahui kekuatan dan kelemahannya, suasana hatinya, temperamennya, keinginannya, dan motivasinya. Siswa harus belajar mengembangkan kecerdasan personal yang tak lain adalah gabungan kecerdasan intrapersonal (cerdas diri) dan kecerdasan interpersonal (cerdas sosial).

Kepedulian orangtua dan guru serta lingkungan sekitarnya terhadap kecerdasan personal, mutlak diperlukan. Berbeda dengan tipe lainnya, perwujudan tipe kecerdasan ini membutuhkan perpaduan dengan tipe kecerdasan lainnya. Misalnya perpaduan dengan kecerdasan bahasa akan melahirkan karya sastra yang berisi pemikiran atau filosofi menakjubkan. Siswa yang menonjol dalam hal ini sering disebut self smart. Konsep diri seorang anak berasal dari pengetahuan yang baik tentang dirinya secara positif, baik itu mengenai mood, temperamen, motivasi, maupun intensinya dalam suatu lingkungan. Tidak cukup sampai di situ, siswa juga harus dapat mengutarakan pendapatnya, keinginannya, kebutuhannya, kekecewaannya, kejengkelannya, atau apa pun yang berkecamuk dalam dirinya. Sehingga dia bisa dipahami dan diterima secara baik oleh lingkungannya. Penerimaan ini akan membuat dirinya menjadi lebih nyaman.

7. Kecerdasan Interpersonal

Kecerdasan interpersonal adalah kemampuan memahami pikiran, sikap, dan perilaku orang lain (Gardner \& Checkley, 1997). Kecerdasan interpersonal adalah kapasitas yang dimiliki oleh seseorang untuk dapat memahami dan dapat melakukan 
interaksi secara aktif dengan orang lain. Kecerdasan ini merupakan kecerdasan dengan indikator-indikator yang menyenangkan bagai orang lain. Sikap-sikap yang ditunjukan oleh anak dalam kecerdasan intrapersonal sangat menyejukan dan penuh kedamaian. Oleh karena itu kecerdasan interpersonal dapat didefenisikan sebagai kemampuan mempersepsi dan membedakan suasana hati, maksud, motivasi dan keinginan orang lain, serta memberikan respon secara tepat terhadap suasana hati, temperamen, dan motivasi orang lain. Komponen ini kecerdasan interpersonal adalah kemampuan mencerna dan menanggapi dengan tepat berbagai suasana hati, maksud, motivasi, perasaan dan keinginan orang lain disamping kemampuan untuk melakukan kerja sama. Komponen lain adalah kepekaan dan kemampuan menangkap perbedaan yang sangat halus terhadap maksud, motivasi, suasana hati, perasaan, dan gagasan orang lain. Kecerdasan interpersonal akan dapat dilihat dari beberapa oranng seperti; guru yang sukses, pekerja sosial, aktor, politisi. Saat ini orang mulai menyadari bahwa kecerdasan interpersonal merupakan salah satu faktor yang sangat kesuksesan seseorang.

Berikut ini individu yang menunjukkan kemampuan dalam inteligensi interpersonal: (a) Mampu menilai diri sendiri dan bermediasi, (b) Mampu mencanangkan tujuan, menyusun cita-cita dan rencana hidup yang jelas, (c) Berjiwa bebas, (d) Mudah berkonsentrasi, (e) Keseimbangan diri, (f) Senang mengekspresikan perasaan - perasaan yang berbeda, dan (g) Sadar akan realitas spiritual Kemampuan personal merupakan suatu keterampilan sosial yang berkaitan dengan ranah afektif dan emosi, seperti masalah etika, motivasi, moral dan hati nurani. Kemampuan personal akan menumbuhsuburkan nilai-nilai kebaikan universal pada diri anak. Diharapkan berkembang menjadi pribadi yang berwatak dan berbudi pekerti luhur; santun, saling menghormati; dan menghargai sesama. Kemampuan personal yang berkembang baik dapat mengembangkan kecerdasan spiritual siswa.

Peran strategi guru dalam indikator yang bisa diterapkan dalam kegiatan pembelajaran yang bisa membantu anak mengembangkan kemampuan interpersonalnya antara lain:

Tabel 2. Indikator untuk Mengembangkan Kemampuan Anak

\begin{tabular}{|c|c|c|}
\hline No & Indikator & Kegiatan \\
\hline 1. & Komunikasi & $\begin{array}{l}\text { Siswa yang tidak dibiasakan berkomunikasi tidak bisa } \\
\text { mengungkapkan keinginannya sehingga dia cenderung } \\
\text { menjadi pribadi yang tertutup. }\end{array}$ \\
\hline 2. & $\begin{array}{l}\text { Hubungan } \\
\text { dengan } \\
\text { orang lain }\end{array}$ & $\begin{array}{l}\text { Seorang pendidik dituntut untuk mampu mengenalkan anak } \\
\text { pada etika, nilai, dan kebiasaan yang berlaku pada } \\
\text { masyarakatnya. Biasakanlah siswa untuk mengucapkan } \\
\text { kalimat-kalimat islami atau agamadan jangan lupa anak } \\
\text { diajarkan untuk bersyukur dan berterima kasih kepada orang } \\
\text { lain, berbagai makanan dengan teman-temannya dan } \\
\text { bagaimana bersikap kepada sesama; kepada orang yang } \\
\text { lebih muda atau orang yang lebih tua. Insya Allah anak akan } \\
\text { tumbuh menjadi anak yang berbudi luhur }\end{array}$ \\
\hline 3. & $\begin{array}{l}\text { Kasih } \\
\text { sayang }\end{array}$ & $\begin{array}{l}\text { Ajarkan anak untuk memiliki rasa kasih sayang pada } \\
\text { sesama, seperti pada orangtua, teman, guru dan orang lain. } \\
\text { Misalnya mengunjungi teman yang sakit atau tidak } \\
\text { mengganggu teman yang lain adalah contoh kasih sayang }\end{array}$ \\
\hline
\end{tabular}


terhadap teman yang bisa diajarkan di sekolah. Begitu pula terhadap makhluk hidup lainnya, seperti tanaman dan binatang piaraan. Misalnya hewan piaraan harus diberi makan dan minum, serta dibersihkan kandangnya.

4. Berbagi Manusia adalah makhluk sosial (Homo Homini Socious). Orang sehebat apa pun tidak akan bisa hidup tanpa bantuan dari orang lain. Oleh karena itu anak dibiasakan untuk mau berbagi. Harus tahu bahwa dalam hidup, dia tidak sendirian; masih ada orang lain yang kondisinya bisa saja berbeda dan perlu dibantu. Ajari anak untuk tidak bersikap pelit lewat kerelaan berbagi bekal atau bertukar makanan di sekolah, berbagai atau saling meminjamkan mainan, dan sebagainya.

5. Kepedulian/ Empati, rasa sayang dan lainnya. Anak diajarkan untuk perhatikan peduli pada sesamanya. Contoh bilama ada temannya yang berulang tahun, ajarilah anak untuk mengucapkan selamat ulang tahun. Jika ada yang kurang mampu, ajarilah anak untuk membagi sebagian miliknya. Atau jika ada temannya yang sakit ajaklah dia untuk menjenguk/menengok temannya sambil membawa buah tangan.

6. Perasaan Anak cenderung sangat ekspresif dengan perasaannya. Jika sedih dia akan menangis; jika marah dia bisa mengamuk; dan jika senang, dia akan tertawa riang. Kadang ada anak yang tidak mampu mengontrol emosinya. Sebagai pendidik ajarlah anak dengan menggambarkan beberapa raut wajah yang menunjukkan berbagai emosi seperti marah, senang, sedih, kecewa, atau kesal sambil menjelaskan masingmasing emosi tersebu

Siswa yang memiliki kecerdasan interpersonal peran guru perlu mengajarkan siswa untuk memilih sesuatu yang benar-benar dia sukai secara asertif (tegas), bukan karena pengaruh atau tekanan dari orang lain. Namun jika pilihan anak itu salah atau tidak sesuai dengan keinginan kita, jelaskan secara lemah lembut dan memintanya untuk mengubah pilihan tersebut. Yang disertai dengan argumen yang bisa mereka terima sehingga mereka tidak merasa sedih atau kecewa.

8. Kecerdasan Naturalis

Keahlian mengenali dan mengkategorikan spesies-flora dan fauna di lingkungannya. Para pecinta alam adalah contoh orang tergolong sebagai orangorang yang memiliki kecerdasan ini. Berikut ini karakteristik individu yang menunjukkan kemampuan dalam inteligensi naturalis yaitu senang terhadap flora dan fauna, bertani, berkebun, memelihara binatang, berinteraksi dengan binatang dan berburu. Pandai melihat perubahan cuaca, meneliti tanaman dan senang kegiatan di alam terbuka Kecerdasan naturalis adalah kemampuan untuk mengenali dan memahami sifatsifat alam. Juga kemampuan untuk bekerja sama dan menyelaraskan diri dengan alam dan senang berada di lingkungan alam yang terbuka, seperti pantai, gunung, cagar alam, atau hutan. Anak-anak dengan kecerdasan ini cenderung suka mengobservasi lingkungan alam, seperti aneka macam bebatuan, jenis-jenis lapisan tanah, aneka macam flora dan fauna, atau 
benda-benda di angkasa. Anak dengan kecerdasan ini berpotensi untuk menjadi ahli/peneliti alam, seperti ahli biologi, ahli botani, antropolog, astronaut, atau petani. Anak yang menonjol dalam hal ini sering disebut nature smart.

Cara guru yang bisa dipakai untuk mengembangkan kecerdasan ini di sekolah antara lain: (1) Mengajak anak untuk menanam dan merawat sendiri tanaman mereka di sekolah, dalam pot atau di kebun sekolah, (2) Di beberapa sekolah ada yang menyediakan hewan piaraan, seperti ayam, atau kambing. Ajak anak didik untuk memberi makan dan memperhatikan pertumbuhan hewan tersebut, dan (3) Sekali-kali anak didik diajak ke kebun binatang atau pertanian, museum, planetarium, dan wahana rekreasi edukatif lainnya.

\section{PENUTUP}

Strategi guru dalam mengoptimalkan kecerdasan majemuk (Multiple Intelligences) yaitu disesuaikan dengan kecerdasan siswa yang dimiliki. Bahwasannya setiap siswa yang dilahirkan telah memiliki karakter potensi dasar yang dapat dikembangkan dan dioptimalkan oleh guru ataupun orangtua. Potensi alamiah dasar dimaksud dalam konsep pendidikan sering diartikan dengan kecerdasan majemuk atau multiple intelligences. Kecerdasan majemuk pada prinsipnya telah dibawa sejak lahir dan dapat dikembangkan melali interaksinya dengan lingkungan termasuk pendidikan. Pengembangan kecerdasan majemuk sangat tergantung kepada lingkungan yang ada atau lingkungan yang diciptakan. Salah satu bentuk lingkungan yang diciptakan adalah proses pembelajaran. Kegitan pembelajaran diyakini dapat mengembangkan kecerdasan majemuk yang ada pada setiap siswa. Guru sebagai pendidik perlu memahami seluk beluk potensi atau kecerdasan yang ada pada siswanya, pemahaman guru akan sangat berpengaruh terhadap upaya yang dilakukannya terutama untuk menghadirkan pengalaman-pengalaman belajar siswa dengan starategi pembelajaran yang tepat. Proses pembelajaran yang dapat mengoptimalkan potensi atau kecerdasan majemuk siswa adalah pembelajaran yang berpusat kepada siswa (student center), siswa diberi kesempatan belajar seluas-luasnya untuk terlibat secara aktif terlibat dengan berbagai kegiatan pembelajaran, sehingga berbagai pengetahuan dapat dibentuk secara aktif dan pembelajaran menjadi bermakna bagi siswa sehingga potensi yang ada pada siswa dapat dioptimalkan. Hasil optimalisasi potensi Multiple Intelligences pada siswa dapat diberikan stimulus berupa penguatan siswa dengan bermain peran, pembelajaran dengan alam, pembelajaran dengan musik dan seni, pembelajaran dengan angka dimana tujuan sistem dan strategi pembelajaran yang tepat sesuai kecerdasan siswa.

\section{UCAPAN TERIMA KASIH}

Ucapan terima kasih penulis sampaikan untuk semua pihak yang terlibat dalam terlaksananya penelitian ini. Terutama pada Dosen yang selalu memberikan bimbingan dan motivasi, lalu pihak dinas pendidikan dan sekolah dasar di kabupaten pandeglang. Tentu tak lupa ucapan terima kasih untuk rekan-rekan satu kelas Program Doktoral Pendidikan Dasar Pascasarjana Universitas Negeri Jakarta yang selalu memberikan motivasi dan semangat untuk sukses bersama.

\section{DAFTARPUSTAKA}

Armstrong, Thomas. 1993. 7 Kinds of Smart: Identifying and Developing Your Intelligences. New York: Penguin Group. 
Armstrong, Thomas. 1996 Multiple Intelligences in The Classroom. Virginia: Association for Supervision and Curriculum Development.

Arifmiboy. (2016). Multiple intelligences: mengoptimalkan kecerdasan anak sebagai upaya dalam mempersiapkan generasi emas masa depan, 69-84.

Astriani, L. W. (2017). Pentingnya Peningkatan Kualitas Guru Untuk Mewujudkan Pentingnya Peningkatan Kualitas Guru Untuk Mewujudkan Generasi Gemilang Yang Berlandaskan Nilai-Nilai Pancasila, (March). Retrieved from https://www.researchgate.net/publication/315107081_PENTINGNYA_PENINGK ATAN_KUALITAS_GURU_UNTUK_MEWUJUDKAN_GENERASI_GEMILA NG_YANG_BERLANDASKAN_NILAI-NILAI_PANCASILA

Baum, Viens, Slatin, 2005. Multiple Intelligences in the Classroom: A Teacher's Toolkit, New York: Teachers Collage Press Campbell, Linda dkk, 2006, Metode Praktis Pembelajaran Berbasis Multiple Intelligences, Depok: Intuisi Press,

Fikriyah, F. Z., \& Aziz, J. A. (2018). Penerapan Konsep Multiple Intelligences pada Pembelajaran PAI. IQ (Ilmu Al-Qur'an): Jurnal Pendidikan Islam, 1(02), 220-244. https://doi.org/10.37542/iq.v1i02.17

Gardner, Howard, 2003, Kecerdasan Majemuk, Teori dalam Praktek, alih bahasa Alexander Sindoro, Batam: Interaksara Gunawan, Adi W., 2006, Genius Learning Strategy: Petunjuk Praktis untuk Menerapkan Accelerated Learning, (Jakarta: PT. Gramedia Pustaka Utama,), Cet. III Guy R. Lefrancois, 1988, Psychology for Teaching, (Belmont: Wadsworth Publishing Company.

Gardner, Howard. 1993. Multiple Intelligences: The Theory in Practice A Reader. New York: Basic Books.

Ira, M. (2015). Sistem Pendidikan di Indonesia: antara keinginan dan realita. Jurnal Auladuna, 2(2), 233-245.

Kanzer, 2001, Theory of Multiple Intellegence: Implication for Higher Education, Inovation Higher Education, Vol. 26 No. 2.

Loe, S. (2017). Mencerahkan bakat Menulis (Tilarasma, ed.). Jakarta: PT. Gramedia Pustaka Utama.

Larlen. (2013). Persiapan Guru Bagi Proses Belajar Mengajar. Pena, 3(1), 81-91.

Marzali, A. (2016). Menulis Kajian Literatur. Jurnal Etnosia, 1(2), 27-36.

McKenzie, Walter, 2005, Multiple Intellegences and Instructional Tehnology, Washington DC: International Society for Tehnology in Education

Nasional, S., \& Ekonomi, P. (n.d.). Pendidikan transformatif dan tantangan masa depan bangsa.

Pratiwi, I. (2019). Efek Program Pisa Terhadap Kurikulum Di Indonesia. Jurnal Pendidikan Dan Kebudayaan, 4(1), 51. https://doi.org/10.24832/jpnk.v4i1.1157

Sri, W. (2017). Ideal Mathedu of Mathematics and Education. Indonesian Digital Journal of Mathematics and Education, 3(5), 285-295. Retrieved from http://idealmathedu.p4tkmatematika.org

Safaria, T. (2005). Interpersonal intelligence: Metode pengembangan kecerdasan anak. Yogyakarta: Amara Books.

Santosa, P. (2015). Metodologi Penelitian Sastra: Paradigma, Proposal, Pelaporan, dan Penerapan.

Sonawat and Gogri, 2008, Multiple Intellegence for Preschool Children, Mumbai: Multi-Tech Publishing 
Suparno, Paul, 2007 Teori Kecerdasan Ganda dan Aplikasinya di Sekolah: Cara Menerapkan Teori Multiple Intelligences Howard Gardner, Yogyakarta: Kanisius, cet. IV

Tanjung. (2018). Pengaruh Kecerdasan Interpersonal dan Penguasaan Diksi terhadap Kemampuan Menulis Cerita Pendek, 1(2), 136-145.

Yaumi Muhammad, 2012, Pembelajaran Berbasis Multiple Intelegences, Dian Rakyat, Jakarta 